\title{
VYUŽITELNOST KOLORIMETRIE PŘI STUDIU HORNIN - NA PŘÍKLADU VÁPENCŮ VE VELKOLOMU MOKRÁ
}

\author{
Application of colorimetry for the study of rocks - the example of limestones from the Mokrá \\ Quarry
}

\author{
Kristýna Dalajková', Jiř́i Zimák', Jindřich Štelc| ${ }^{2,3}$, Dalibor Všianský \\ ${ }^{1}$ Katedra geologie PřF UP, tř. 17. listopadu 12, 771 46 Olomouc; e-mail:jiri.zimak@upol.cz \\ 2 Ústav geologických věd PřF MU, Kotlářská 2, 61137 Brno \\ ${ }^{3}$ Katedra biologie PedF MU, Poříči 7, 60300 Brno
}

(24-41 Vyškov)

Key words: Moravian Karst, limestones, colorimetry

\begin{abstract}
The paper summarizes the results of colorimetric analyses of a large set of limestone samples from the Mokrá Quarry in the Moravian Karst (NE from Brno, Czech Republic). The examined samples belong to three lithologically different series of strata: Macocha, Líšen,, and Březina Formations. Limestones of these formations differ in the contents of non-carbonate component and, hence, in colour. The samples were prepared in four ways for colorimetric measurements: 1. unpolished bulk samples (cleavage planes were measured), 2. polished sections, 3. powder in a plastic bag, 4. simple uncovered powder. All of the four ways of sample preparation led to different results. The results were expressed using a CIE $L^{*} a^{*} b^{*}$ colour space. Based on the $L^{*}$ (specific lightness) value, the amounts of a non-carbonate component can be roughly judged. The specific lightness can be used for assigning a sample to a lithostratigraphic member and possibly also to correlation reasons in many cases.
\end{abstract}

Úvod

Patrně každý geolog se již setkal s problémem vyjádřit jednoznačným způsobem barvu popisované horniny a v prípadě kolektivní práce se slovní vyjádření barvy mohlo stát i předmětem sporu. Nejednotné a značně subjektivní hodnocení a označování barvy hornin lze zčásti odstranit použitím Munsellova systému, kdy se nezbytnou pomůckou stává „Munsellova kniha barev“" (s 1452 kartičkami barev) nebo „Munsellův vějiŕ limitních barev“ (vhodný do terénu, umožňuící rozlišit 768 barev) - podrobně např̀ Jiránek (1981).

Pomocí spektrometru vhodné konstrukce lze barvu horniny exaktně změřit. Tato problematika není v geologické literatuře doposud př́liš ř rešena, s výjimkou relativně malého počtu prací, které se převážně zabývají hodnocením sedimentů, včetně stratigrafie (Wells et al. 2002; Hu et al. 2014), a také prací orientovaných pedologicky (Adderley et al. 2002; Ibáñez-Asensio et al. 2013; Cancelo-González et al. 2014). Mimo disciplín spadajících do oblasti věd o Zemi nacházejí výsledky kolorimetrických měření uplatnění i v řadě odlišně zaměřených oborů lidské činnosti, např́klad v archeologii (Oestmo 2013; Ruiz-Pereira 2014), $\mathrm{v}$ restaurátorství, malírství a dalších umělecky orientovaných oborech (Cochrane 2014), v potravinářství (Kljak et al. 2014; Sánchez-Zapata et al. 2011; García-Marino et al. 2013) nebo v lékařství (Chang et al. 2012). Analýzy bývají prováděny ve dvou barevných prostorech - CIE $L^{\star} a^{*} b^{*}$ a CIE $L^{\star} C^{\star} h^{\star}$. Podrobnou charakteristiku obou barevných prostorů, jejich vzájemný vztah i možnosti využití uvádí např. Zmeškal et al. (2002), Viscarra Rossel et al. (2006) a Korifi et al. (2013). Je velmi pravděpodobné, že k objektivnímu hodnocení barev hornin, půd apod. bude možno využít i mobilní telefony s kamerou, vybavené potřebným softwarem, umožňujícím charakterizovat barvu pomocí parametrů užívaných Munsellovým systémem nebo systémem CIE (Gómez-Robledo et al. 2013).

$\mathrm{V}$ tomto článku jsou sumarizována data získaná kolorimetrickým měřením pomocí spektrofotometru SP 62 na velkém souboru vzorkủ vápenců z velkolomu Mokrá v Moravském krasu, a to jako součást komplexního studia hornin z této lokality. Některé poznatky mají zásadní význam $\mathrm{z}$ hlediska volby pracovních postupů.

\section{Materiál a metody}

K výzkumu bylo použito 120 vzorků vápenců a vápnitých siliciklastik (siltových břidlic) odebraných ve všech třech částech velkolomu Mokrá. $\mathrm{V}$ tomto souboru vzorků jsou zastoupeny jak světlé a relativně čisté vápence macošského souvrství, tak zpravidla výrazně tmavší a na nekarbonátovou složku bohatší vápence souvrství líšeňského a březinského, provázené výše zmíněnými siliciklastiky (nejzákladnější údaje o petrografických poměrech ve velkolomu Mokrá uvádí např. Rez 2010). Vzorky o hmotnosti zhruba 400 gramů byly vysušeny, rozdrceny a následně rozemlety v planetovém mlýnu. Rozkladem v kyselině octové $(8 \%)$ byl $\mathrm{v}$ rozpráškovaných vzorcích stanoven podíl nerozpustné (nekarbonátové) složky. Ze vzorků vápenců byly zhotoveny nábrusy o rozměrech minimálně $15 \times 15 \mathrm{~mm}$.

Kolorimetrická měření byla provedena na všech 120 horninových vzorcích (na lomných plochách), na 71 nábrusech vápenců, které byly pro tato měření vhodné (naleštěná plocha byla barevně víceméně jednolitá), a také na rozpráškovaných horninových vzorcích. 
Tab. 1: Vápence z velkolomu Mokrá ve standardních barevných prostorech CIE L*a* $\mathrm{b}^{*}$ a $\mathrm{CIE} L^{*} \mathrm{C}^{\star} h^{\circ}$.

Table 1: Limestones from the Mokrá Quarry in standard color spaces CIE $\mathrm{L}^{\star} \mathrm{a}^{*} \mathrm{~b}^{\star}$ a CIE $L^{\star} C^{\star} h^{\circ}$.

\begin{tabular}{|c|c|c|c|c|c|c|c|c|c|c|c|c|c|}
\hline & \multicolumn{4}{|c|}{ macošské souvrství } & \multicolumn{4}{|c|}{ líšeňské souvrství } & \multicolumn{4}{|c|}{ březinské souvrství } \\
\hline & & LP & $\mathrm{N}$ & PV & PS & LP & $\mathrm{N}$ & PV & PS & LP & $\mathrm{N}$ & PV & PS \\
\hline \multirow{3}{*}{$\mathrm{L}^{*}$} & $\min$. & 34,80 & 38,50 & 83,30 & 85,60 & 25,10 & 26,50 & 62,10 & 67,70 & 21,00 & 30,10 & 59,40 & 67,70 \\
\hline & max. & 63,10 & 51,60 & 93,20 & 94,00 & 56,90 & 48,60 & 89,40 & 90,50 & 55,90 & 56,20 & 82,30 & 84,30 \\
\hline & med. & 47,80 & 45,40 & 87,60 & 89,60 & 34,80 & 35,80 & 76,60 & 80,10 & 33,80 & 34,80 & 73,20 & 78,90 \\
\hline \multirow{3}{*}{$a^{*}$} & $\min$ & 0,60 & 0,54 & 0,48 & 0,33 & $-0,83$ & $-0,12$ & 0,12 & 0,18 & 0,17 & 0,12 & 0,76 & 0,62 \\
\hline & $\max$. & 5,08 & 5,08 & 1,38 & 1,17 & 4,04 & 2,97 & 2,39 & 1,96 & 1,65 & 1,71 & 2,29 & 1,82 \\
\hline & med. & 1,00 & 1,01 & 0,67 & 0,56 & 0,70 & 0,63 & 1,60 & 1,22 & 0,32 & 0,42 & 1,14 & 0,87 \\
\hline \multirow{4}{*}{$o^{*}$} & min. & 2,95 & 2,97 & 3,41 & 2,87 & 0,71 & 0,40 & 4,09 & 3,17 & 0,46 & 0,67 & 4,89 & 3,64 \\
\hline & max. & 17,13 & 14,43 & 10,81 & 9,35 & 16,88 & 11,01 & 12,21 & 10,35 & 7,18 & 6,05 & 10,06 & 7,78 \\
\hline & med. & 4,58 & 4,49 & 4,69 & 3,76 & 2,82 & 2,62 & 7,63 & 6,00 & 1,26 & 1,43 & 6,78 & 5,40 \\
\hline & $\min$. & 3,01 & 3,03 & 3,48 & 2,91 & 0,74 & 0,47 & 4,15 & 3,21 & 0,52 & 0,68 & 5,03 & 3,75 \\
\hline \multirow[t]{3}{*}{$c^{*}$} & $\max$. & 17,87 & 15,21 & 10,90 & 9,43 & 16,99 & 11,40 & 12,29 & 10,42 & 7,37 & 6,28 & 10,20 & 7,86 \\
\hline & med. & 4,68 & 4,66 & 4,75 & 3,80 & 2,89 & 2,71 & 7,86 & 6,17 & 1,32 & 1,50 & 6,86 & 5,59 \\
\hline & $\min$. & 73,47 & 70,49 & 78,75 & 66,68 & 68,43 & 57,33 & 74,58 & 73,00 & 61,51 & 65,06 & 74,82 & 72,92 \\
\hline \multirow[t]{2}{*}{0} & max. & 83,94 & 84,81 & 86,37 & 87,21 & 106,82 & 93,05 & 88,71 & \begin{tabular}{|l}
87,56 \\
\end{tabular} & \begin{tabular}{|l}
81,39 \\
\end{tabular} & \begin{tabular}{|l|l}
83,08 \\
\end{tabular} & 83,54 & 83,71 \\
\hline & med. & 77,38 & 77,03 & 81,53 & 81,19 & 76,76 & 75,65 & 78,72 & 78,92 & 75,98 & 75,87 & 79,40 & 79,16 \\
\hline
\end{tabular}

na povrchu sáčku vytvořena rovná plocha a současně byly odstraněny vzduchové bubliny mezi práškem a PE-fólií, potom bylo provedeno měření (PS v tab. 1). Druhý z postupů snižuje riziko znečištění přístroje. Měření byla realizována na katedře geologie PřF UP Olomouc pomocí spektrofotometru SP 62 v režimu SPIN, D65, zorný úhel $10^{\circ}$, snímáno bylo viditelné spektrum v rozsahu 400 až 700 nm. Každé měření sestávalo ze dvou dílčích, $\mathrm{z}$ nichž byl vypočten průměr, s nímž se dále pracovalo.

Kolorimetrická data jsou vyjádřena v barevných prostorech CIE $L^{\star} a^{\star} b^{\star}$ a CIE $L^{\star} C^{\star} h^{\circ}$. Ve standardním barevném prostoru CIE $\mathrm{L}^{\star} \mathrm{a}^{\star} \mathrm{b}^{\star}$ jsou tři navzájem kolmé osy: měrná světlost $\mathrm{L}^{*}$ a dvě chromatické osy a $a b^{*}$. Měrná světlost nabývá hodnot

Při měření rozpráškovaných vzorků byly použity dva rozdílné postupy: a) prášek byl nasypán na podložku, povrch jeho několik mm silné vrstvy byl srovnán, lehce stlačen pravítkem a na takto připravené ploše bylo provedeno kolorimetrické měření ( $\mathrm{v}$ tabulce 1 tento postup označen jako PV), b) prášek v „bezbarvém“ sáčku z nízkohustotního PE byl umístěn na podložku, tlakem pravítka byla

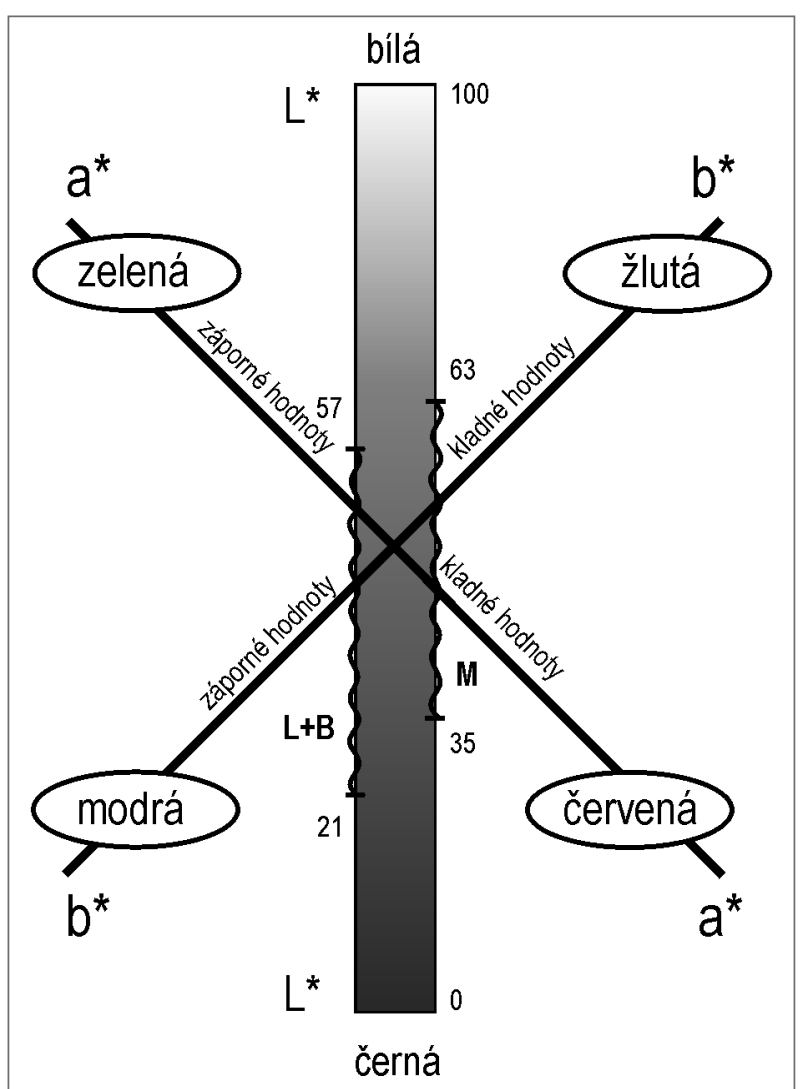

Obr. 1: Schématické znázornění standardního barevného prostoru CIE $L^{*} a^{*} b^{*}$.

Fig. 1: Schematic drawing of a standard color space CIE $L^{*} a^{\star} b^{*}$. v intervalu od 0 (černá) do 100 (bílá); chromatická osa a probíhá od zelené barvy (záporné hodnoty) po červenou (kladné hodnoty), osa $b^{\star}$ od modré (záporné hodnoty) ke žluté (kladné hodnoty) - viz obrázek 1 . Ve standardním barevném prostoru CIE $\mathrm{L}^{\star} \mathrm{C}^{\star} h^{\circ}$ jsou chromatické souřadnice $a^{\star} a b^{\star}$ prevevedeny na sytost barvy $C^{\star}$ (přesněji $C^{\star} a b$, angl.. „chroma“) a barevný tón či měrný úhel barevného tónu $\mathrm{h}^{\circ}$ (přesněji $\mathrm{h}^{\circ}{ }_{\mathrm{ab}}$, angl. „hue ${ }^{\text {“) }}$.

\section{Výsledky a diskuze}

Výsledky všech provedených kolorimetrických měření jsou sumarizovány v tabulce 1 . Významné nebo zajímavé poznatky jsou komentovány v následujících odstavcích:

1. Kolorimetrická měření provedená pomocí spektrálního fotometru SP 62 jsou dobře reprodukovatelná v př́padě barevně víceméně homogenních nábrusů a rozpráškovaných hornin. Při opakovaných měřeních na relativně rovných lomných plochách vápenců byly sice zjištěny rozdílné hodnoty měrné světlosti $\left(\mathrm{L}^{*}\right)$ i určité rozdíly v hodnotách obou chromatických parametrů ( $\mathrm{a}^{\star} \mathrm{a} \mathrm{b}^{\star}$ nebo $C^{\star} a h^{\circ}$ ), avšak intervaly naměřených hodnot jsou natolik úzké, že i výsledky měření na lomných plochách hornin lze považovat za použitelné.

2. Nejvhodnějším materiálem pro kolorimetrická měření jsou rozpráškované vzorky. $\mathrm{V}$ případě hornin $\mathrm{z}$ velkolomu Mokrá byl rozpráškováním odstraněn problém $s$ barevnou nehomogenitou některých vápenců a obecně může být „prášek“ využit ke kolorimetrii hornin, jejichž zrnitost neumožňuje provedení reprezentativních měření na horninovém vzorku. Oba výše popsané postupy měření práškových preparátů poskytují rozdílné výsledky, a to zejména $\mathrm{v}$ prrípadě měrné světlosti, která je při měření za použití sáčku vyšší, a to velmi výrazně u vzorků s nízkými hodnotami $\mathrm{L}^{\star}$ až zcela nepodstatně u vzorků s vysokými hodnotami L* (obr. 2). Nutno poznamenat, že výsledek měření je ovlivněn vlastnostmi fólie, $\mathrm{z}$ níž je sáček zhotoven (včetně tlouštky fólie). Obrázek 2 dokumentuje i výraznou 


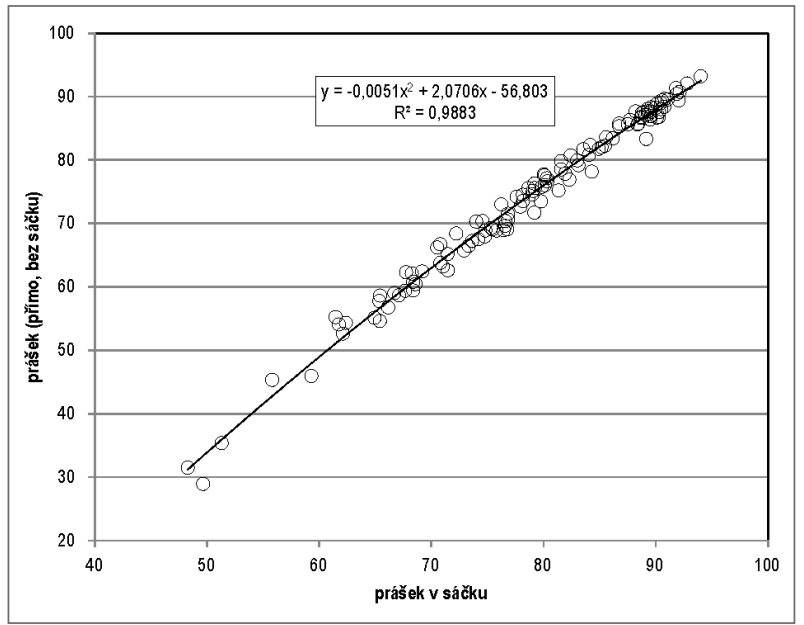

Obr. 2: Vztah měrné světlosti $L^{*}$ prášku v sáčku a prášku měřeného prímo (bez sáčku).

Fig. 2: Correlation of specific lightness $\mathrm{L}^{\star}$ of the powder analysed in a plastic bag and directly (outside).

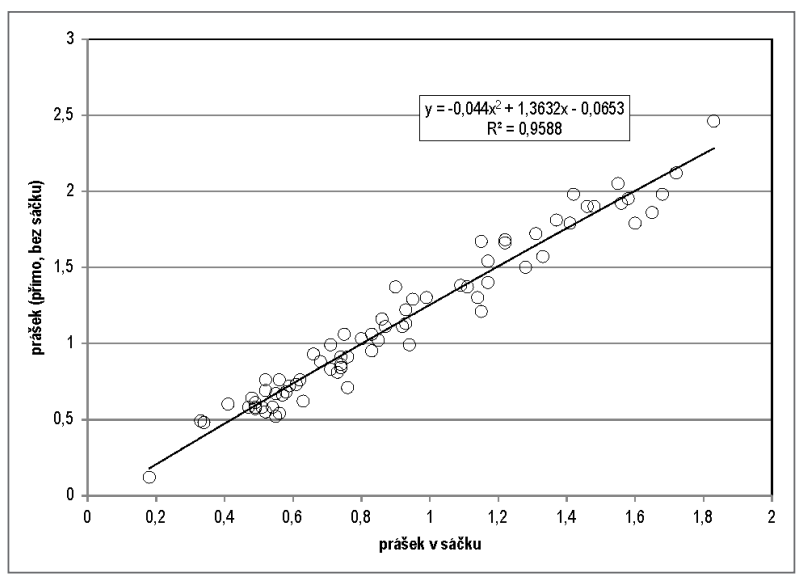

Obr. 3: Vztah chromatického parametru a ${ }^{*}$ prášku v sáčku a prášku měřeného přímo (bez sáčku).

Fig. 3: Correlation of a chromatic parameter $\mathrm{a}^{*}$ of the powder analysed in a plastic bag and directly (outside).

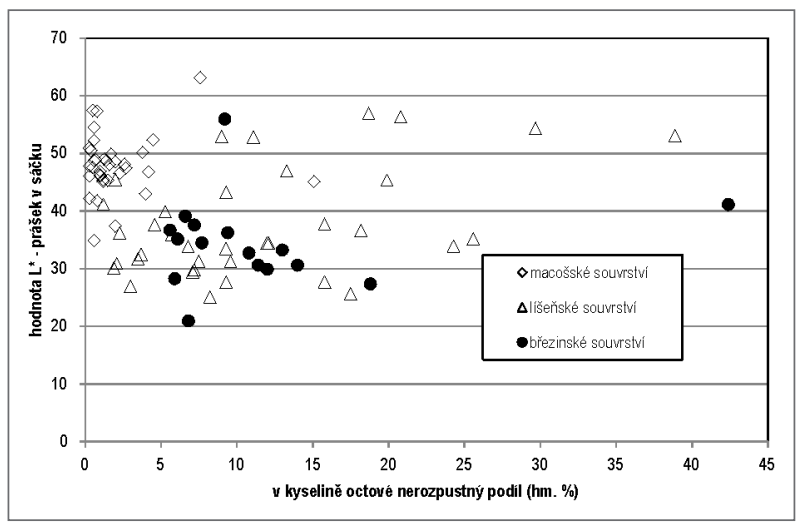

Obr. 4: Vztah mezi množstvím nekarbonátové složky ve vápenci a měrnou světlosti $L^{*}$ zjištěnou měřením prášku $\mathrm{v}$ sáčku.

Fig. 4: Correlation of the amount of carbonate component in limestone and the specific ligthtness $\mathrm{L}^{*}$ of the powder in a plastic bag.

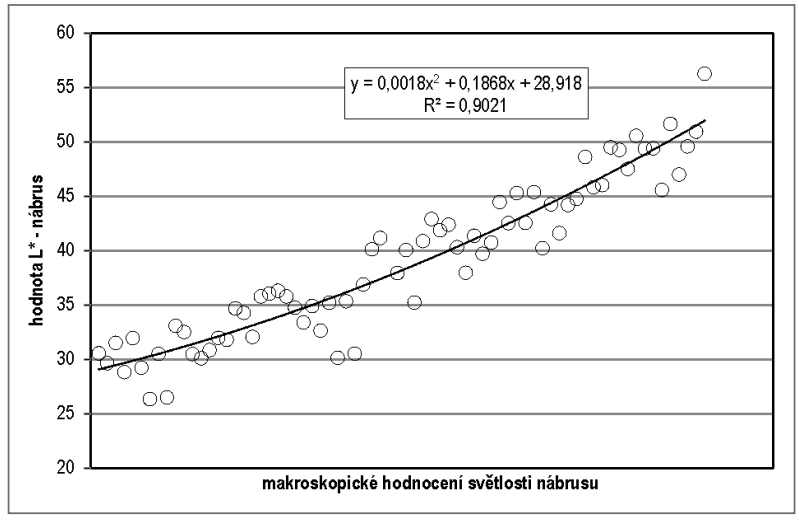

Obr. 5: Vztah mezi vizuálním hodnocením pozice naleštěné plochy vápence $v$ řadě černá-bílá a měrnou světlostí $L^{*}$ změřenou na této ploše.

Fig. 5: Correlation between visual evaluation of the position of limestone polished area in the black-white scale and a specific lightness $\mathrm{L}^{*}$ of this area.

pozitivní korelaci mezi hodnotami měrné světlosti zjištěnými oběma postupy (koeficient determinace $\mathrm{R}^{2}$ je 0,99 ). Hodnoty $\mathrm{a}^{*} \mathrm{a} \mathrm{b}^{*}$ stanovené oběma postupy jsou vždy kladné a nízké (tab. 1), $\mathrm{R}^{2}$ je u obou chromatických parametrů shodně 0,96 , hodnota $b^{*}$ stanovená měřením za použití sáčku je vždy o něco nižší (alespoň v daném intervalu hodnot), vztahy $\mathrm{v}$ př́padě $\mathrm{a}^{*}$ jsou zřejmé $\mathrm{z}$ obrázku 3.

3. Vztahy mezi hodnotami $L^{*}, a^{*} a b^{*}$ zjištěnými měřeními na prášku $\mathrm{v}$ sáčku (PS), lomné ploše vzorku $(\mathrm{LP})$ a na nábrusu $(\mathrm{N})$ lze hodnotit takto: $\mathrm{V}$ př́padě $\mathrm{L}^{*}$ existuje významná pozitivní korelace mezi hodnotami stanovenými na $\mathrm{LP}$ a na $\mathrm{N}\left(\mathrm{R}^{2}=0,72\right.$ pro polynomickou funkci), mezi hodnotami zjištěnými na PS a na N $\left(\mathrm{R}^{2}=\right.$ 0,69 ), ne však mezi hodnotami na LP a na PS (pozitivní korelace $s R^{2}=0,31$ ). Pro jednotlivé vzorky ve většině př́padů platí, že nejnižší hodnoty $L^{*}$ byly zaznamenány u LP a N, přičemž zpravidla $L P<N$. Hodnoty $L^{*}$ pro PV a PS jsou vždy výrazně vyšší a vždy $\mathrm{PV}<\mathrm{PS}$.

U obou chromatických parametrů je významná pozitivní korelace jedině mezi výsledky měření na $\mathrm{LP}$ a na $\mathrm{N}$, a to pouze v prípadě $a^{*}\left(R^{2}=0,56\right)$.

4. Karbonátové horniny macošského, líšeňského a březinského souvrství vznikly za rozdílných podmínek (viz např. Rez 2010), a s tím souvisí obecně známé rozdíly v jejich složení („čisté" vápence macošského souvrství versus na nekarbonátovou složku zpravidla bohaté vápence líšeňského a březinského souvrství) a také $v$ barvě (světlé vápence macošského souvrství, často tmavé až téměř černé vápence liššňského a březinského souvrství). Pokud jde o barvu, je rozdíl mezi vápenci těchto souvrství zřejmý $\mathrm{z}$ údajů $\mathrm{v}$ tabulce 1 a také $\mathrm{z}$ obrázku 1 , na němž jsou vyjádřena rozpětí hodnot měrné světlosti $\left(\mathrm{L}^{*}\right)$ pro vápence macošského souvrství $(M)$ a souvrství líšeňského a březinského $(\mathrm{L}+\mathrm{B})$. Obrázek 4 znázorňuje vztah mezi obsahem nekarbonátové složky a měrnou světlostí vápenců macošského, lí̌seňského a březinského souvrství.

5. Na obrázku 5 je srovnání vizuálního hodnocení barvy nábrusů (na vodorovné ose - nábrusy jsou seřazeny od nejtmavšího vlevo $k$ nejsvětlejšímu vpravo) s naměřenými hodnotami měrné světlosti. Je zřejmé, že vizuální 
hodnocení je poměrně spolehlivé pokud jde o rozlišení mezi tmavší a světlejší horninou ve škále bílá-černá.

\section{Závěr}

$\mathrm{Na}$ rozdíl od vizuálního hodnocení umožňují kolorimetrická měření vyjádřit barvu horniny exaktně. Reprezentativní měření pomocí spektrálního fotometru SP 62 jsou proveditelná na rozpráškovaných horninových vzorcích a na relativně rovných lomných plochách jemnozrnných nebo celistvých hornin (případně na nábrusech z těchto hornin). Ve srovnávaném souboru vzorků musí být měření realizována za stejných podmínek. To platí i pro měření rozpráškovaných horninových vzorků v „bezbarvých“ sáčcích (nutno použít sáčky zhotovené ze stejného materiálu). Použitý spektrální fotometr není vhodný pro terénní měření, na trhu jsou však v současné době k dispozici i analogické prrístroje $\mathrm{v}$ „outdoorovém“ provedení (užívané již běžně např̀ v archeologii a pedologii).

V př́padě karbonátových hornin z velkolomu Mokrá lze na základě kolorimetrimetrických měření (podle hodnoty měrné světlosti $L^{*}$ ) orientačně posoudit množství nekarbonátové složky ve studované hornině. $\mathrm{V}$ řadě případů lze měrnou světlost vápence využít $\mathrm{k}$ jeho přiřazení $\mathrm{k}$ jednotlivým litostratigrafickým členům a k případným korelačním účelům $\mathrm{v}$ dobývacím prostoru ložiska Mokrá. Některé v diskuzi naznačené závislosti bude nutno ještě prověřit na kvantitativně rozsáhlejším souboru vzorků jak z velkolomu Mokrá, tak případně i z dalších lokalit v j. části Moravského krasu.

\section{Literatura}

Adderley, W. P. - Simpson, I. A. - Davidson, D. A. (2002): Colour description and quantification in mosaic images of soil thin sections. - Geoderma 108, 181-195.

Cancelo-González, J. - Cachaldora, C. - Díaz-Fierros, F. - Prieto, B. (2014): Colourimetric variations in burnt granitic forest soils in relation to fire severity. - Ecological Indicators 46, 92-100.

Cochrane, S. (2014): The Munsell Color System: A scientific compromise from the world of art. - Studies in History and Philosophy of Science 47, 26-41.

García-Marino, M. - Escudero-Gilete, M. L. - Heredia, F. J. - Escribano-Bailón, M. T. - Rivas-Gonzalo, J. C. (2013): Color-copigmentation study by tristimulus colorimetry (CIELAB) in red wines obtained from Tempranillo and Graciano varieties. - Food Research International 51, 123-131.

Gómez-Robledo, L. - López-Ruiz, N. - Melgosa, M. - Palma, A. J. - Capitán-Vallvey, L. F. - Sánchez-Marañón, M. (2013): Using the mobile phone as Munsell soil-colour sensor: An experiment under controlled illumination conditions. - Computers and Electronics in Agriculture 99, 200-208.

Hu, X.-F. - Du, Y. - Guan Ch.-L. - Xue, Y. - Zhang, G.-L. (2014): Color variations of the Quaternary Red Clay in southern China and its paleoclimatic implications. - Sedimentary Geology 303, 15-25.

Chang, J.-Y. - Chen, W.-Ch. - Huang T.-K. - Wang J.-Ch. - Fu, P.-S. - Chen J.-H. - Hung Ch.-Ch. (2012): Evaluating the accuracy of tooth color measurement by combining the Munsell color system and dental colorimeter. - Kaohsiung Journal of Medical Sciences 28, 490-494.

Ibáñez-Asensio, S. - Marqués-Mateu, A. - Moreno-Ramón, H. - Balasch, S. (2013): Statistical relationships between soil colour and soil attributes in semiarid areas. - Biosystems Engineering 116, 120-129.

Jiránek, J. (1981): Objektivní hodnocení barev hornin a minerálů. - Geologický průzkum 23, 5, 149-151.

Kljak, K. - Grbeša, D. - Karolyi, D. (2014): Reflectance colorimetry as a simple method for estimating carotenoid content in maize grain. - Journal of Cereal Science 59, 109-111.

Korifi, R. - Le Dréau Y. - Antinelli, J.-F. - Valls, R. - Dupuy, N. (2013): CIELª ${ }^{\star}{ }^{\star}$ color space predictive models for colorimetry devices - Analysis of perfume quality. - Talanta 104, 58-66.

Oestmo, S. (2013): Digital imaging technology and experimental archeology: a methodological framework for the identification and interpretation of fire modified rock (FMR). - Journal of Archaeological Science 40, 4429-4443.

Rez, J. (2010): Strukturně-geologický vývoj jižní části Moravského krasu. - MS, disertační práce, PřF MU Brno. (dostupné on-line)

Ruiz, J. F. - Pereira, J. (2014): The colours of rock art. Analysis of colour recording and communication systems in rock art research. - Journal of Archaeological Science 50, 338-349.

Sánchez-Zapata, E. - Fuentes-Zaragoza, E. - Navarro-Rodríguez de Vera, C. - Sayas, E. - Sendra, E. - Fernández-López, J. - Pérez-Alvarez, J. A. (2011): Effects of tuna pâté thickness and background on CIEL $\mathrm{a}^{\star} \mathrm{b}^{\star}$ color parameters and reflectance spektra. - Food Control 22, 1226-1232.

Viscarra Rossel, R. A. - Minasny, B. - Roudier, P. - McBratney, A. B. (2006): Colour space models for soil science. - Geoderma 133, 320- 337.

Wells, N. A. - Konowal, M. - Sundback, S. A. (2002): Quantitative evaluation of color measurements II. Analysis of Munsell color values from the Colton and Green River Formations (Eocene, central Utah). - Sedimentary Geology 151, 17-44.

Zmeškal, O. - Čeppan, M. - Dzik, P. (2002): Barevné prostory a správa barev. [http://www.fch.vutbr.cz/lectures/imagesci/download/stud06_rozn02.pdf. 